25 Vanner SJ, Depew WT, Paterson WG, et al. Predictive value of the Rome criteria for diagnosing the irritable bowel syndrome. Am J Gastroenterol 1999;94:2912-7.

26 Thompson WG, Longstreth GF, Drossman DA, et al. Functional bowel disorders and functional abdominal pain. Gut, 1999;45(Suppl 2), 43-7.

27 Lee FI, Costello FT. Crohn's disease in Blackpool incidence and prevalence 1968-80. Gut 1985;26:274-8.

28 Sanders DS, Hurlstone DP, Stokes RO, et al. Changing face of adult coeliac disease: experience of a single university hospital in South Yorkshire. Postgrad Med J 2002;78:31-3.

29 Sanders DS, Carter MJ, Hurlstone DP, et al. Association of adult coeliac disease with irritable bowel syndrome: a case-control study in patients fulfilling ROME II criteria referred to secondary care. Lancet 2001;358:1504-8.

30 Ciclitira PJ, King AL, Fraser JS. AGA technical review on Celiac Sprue. American Gastroenterological Association. Gastroenterology 2001;120:1526-40.

31 Chester AC, MacMurray FG, Restifo MD, et al. Giardiasis as a chronic disease. Dig Dis Sci 1985:30:215-18.

32 Bendig DW. Diagnosis of giardiasis in infants and children by endoscopic brush cytology. J Pediatr Gastroenterol Nutr 1989:8:204-6.

33 Farthing MJ. Giardiasis. Gastroenterol Clin North Am 1996;25:413-515.

34 Vesy CJ, Peterson WL. Review article: the management of Giardiasis. Aliment Pharmacol Ther 1999; 13:843-50.

35 Loftus EV. Microscopic colitis: epidemiology and treatment. Am J Gastroenterol 2003;98:S31-6.

36 Olesen M, Eriksson S, Bohr J, et al. Lymphocytic colitis: a retrospective clinical study of 199 Swedish patients. Gut 2004;53:536-41.

37 Olesen M, Eriksson S, Bohr J, et al. Microscopic colitis: a common diarrhoeal disease. An epidemiological study in Orebro, Sweden, 19931998. Gut 2004;53:346-50.

38 Fernandez-Banares $F$, Esteve $M$, Salas $A$, et al. Bile acid malabsorption in microscopic colitis and in previously unexplained functional chronic diarrhea. Dig Dis Sci 2001:46:2231-8.

39 Bolin TD, Davis AE, Duncombe VM. A prospective study of persistent diarrhoea. Aust N Z J Med 1982;12:22-6
40 Zigmond AS, Snaith RP. The hospital anxiety and depression scale. Acta Psychiatr Scand 1983:67:361-70.

41 Kruis W, Thieme C, Weinzierl M, et al. A diagnostic score for the irritable bowel syndrome. Its value in the exclusion of organic disease. Gastroenterology 1984;87:1-7.

42 Creed F. The relationship between psychosocial parameters and outcome in irritable bowel syndrome. Am J Med 1999; 107:74S-80S

43 Whitehead WE, Bosmaiian $\mathrm{L}$, Zonderman $\mathrm{AB}$, et al Symptoms of psychologic distress associated with irritable bowel syndrome. Comparison of community and medical clinic samples. Gastroenterology 1988;95:709-14.

44 Smith RC, Greenbaum DS, Vancouver JB, et al. Psychosocial factors are associated with health care seeking rather than diagnosis in irritable bowel syndrome. Gastroenterology 1990;98:293-301.

45 Hamm LR, Sorrells SC, Harding JP, et al. Additional investigations fail to alter the diagnosis of irritable bowel syndrome in subjects fulfilling the Rome criteria. Am J Gastroenterol 1999;94:1279-82.

46 Tolliver BA, Herrera JL, DiPalma JA. Evaluation of patients who meet clinical criteria for irritable bowe syndrome. Am J Gastroenterol 1994;89:176-8.

47 Jones JIW, Richardson P, Hebden JM, et al. Value of simple screening tests for the diagnosis of chronic diarrhoea. Gut 1999;44:A12.

48 Gilat T, BenHur H, Gelman-Malachi E, et al. Alterations of the colonic flora and their effect on the hydrogen breath test. Gut 1978;19:602-5.

49 Newcomer AD, McGill DB, Thomas PJ, et al. Tolerance to lactose among lactase-deficient American Indians. Gastroenterology 1978;74:44-6

50 Palmer KR, Corbett CL, Holdsworth CD. Doubleblind cross-over study comparing loperamide, codeine and diphenoxylate in the treatment of chronic diarrhea. Gastroenterology 1980;79:1272-5.

51 Cann PA, Read NW, Brown C, et al. Irritable bowe syndrome: relationship of disorders in the transit of a single solid meal to symptom patterns. Gut 1983;24:405-11

52 Lavo B, Stenstam M, Nielsen A-L. Loperamide in treatment of irritable bowel syndrome - A doubleblind placebo controlled study. Scand J Gastroenterol 1987;22:77-80.
53 Cremonini F, Delgado-Aros S, Camilleri M. Efficacy of alosetron in irritable bowel syndrome: a metaanalysis of randomized controlled trials. Neurogastroenterol Motil 2003;15:79-86.

54 Glaxo Wellcome withdraws irritable bowel syndrome medication. FDA Consum 2001;35:3

55 Camilleri M. Safety concerns about alosetron. Arch Intern Med 2002;162:100-1.

56 Friedel D, Thomas R, Fisher RS. Ischemic colitis during treatment with alosetron. Gastroenterology $2001 ; 120: 557-60$

57 Kamm MA. Review article: the complexity of drug development for irritable bowel syndrome. Aliment Pharmacol Ther 2002;16:343-51.

58 Wolfe SG, Chey WY, Washington MK, et al. Tolerability and safety of alosetron during long-term administration in female and male irritable bowel syndrome patients. Am J Gastroenterol 2001;96:803-11.

59 Williams AJK, Merrick MV, Eastwood MA. Idiopathic bile acid malabsorption - A review of clinical presentation, diagnosis, and response to treatment. Gut 1991;32:1004-6.

60 Sinha L, Liston R, Testa HJ et al Idiopathic bile acid malabsorption: qualitative and quantitative clinical features and response to cholestyramine. Aliment Pharmacol Ther 1998;12:839-44.

61 Clouse RE, Lustman PJ, Geisman RA, et al. Antidepressant therapy in 138 patients with irritable bowel syndrome: A five-year clinical experience. Aliment Pharmacol Ther 1994;8:409-16.

62 Rajagopalan M, Kurian G, John J. Symptom relief with amitriptyline in the irritable bowe syndrome. J Gastroenterol Hepatol 1998;13:738-41.

63 Greenbaum DS, Mayle JE, Vanegeren LE, et al Effects of desipramine on irritable bowel syndrome compared with atropine and placebo. Dig Dis $\mathrm{Sci}_{\mathrm{i}}$ 1987:32:257-66.

64 Jackson JL, O'Malley PG, Tomkins G, et al. Treatment of functional gastrointestinal disorders with antidepressant medications: a meta-analysis. Am J Med 2000;108:65-72

65 Drossman DA, Toner BB, Whitehead WE, et al. Cognitive-behavioral therapy versus education and desipramine versus placebo for moderate to severe functional bowel disorders. Gastroenterology 2003;125:19-31.

\title{
Crohn's disease or abdominal tuberculosis?
}

\section{A Forbes}

T his is an introduction to the Gut tutorial "Crohn's disease or abdominal tuberculosis?" hosted on BMJ Learning - the best available learning website for medical professionals from the BMJ Group.

A case-based discussion highlights recent trends in the investigation of patients suspected to have Crohn's disease and their management. The phenotype of Crohn's disease can be more accurately described using Vienna classification and formal assessment of disease activity can be performed using Crohn's Disease Activity Index or Harvey Bradshaw index, although their application in routine practice remains limited. Conventional tests, such as barium follow through, are still useful in the investigation of patients with symptoms and signs suggestive of small bowel disease, whereas non-invasive tests, such as ultrasound, may assist in decision making, such as indication and timing of surgery in Crohn's disease. Ileocaecectomy with removal of all macroscopic disease is followed by sustained remission for up to 10 years in roughly $30 \%$ of Crohn's disease patients who receive no further treatment. However, meta-analysis demonstrates a small but statistically significant benefit from the use of mesalazine in prolonging remission in patients in whom the remission has been obtained surgically. Limited data available suggest that azathioprine provides benefit in the post-operative Crohn's patient. Stopping smoking is effective in prolonging remission in Crohn's disease.

To access the tutorial (Interactive Case History), click on BMJ Learning: Take this module on BMJ Learning from the content box at the top right and bottom left of the online article. For more information please go to: http://gut.bmj. com/tutorials/collection.dtl

If prompted, subscribers must sign into Gut with their journal's username and password. All users must also complete a one-time registration on BMJ Learning and subsequently log in (with a BMJ Learning username and password) on every visit.

Gut 2007;56:1757-1758. doi: $10.1136 /$ gut.2007.138875

Correspondence to: A Forbes, St Mark's Hospita and Academic Institute, Watford Road, Harrow HA1 3UJ, UK; alastair.forbes@ic.ac.uk

Competing interests: None. 


\section{REFERENCES}

1 Larsen TB, Nielsen JN, Fredholm L, et al. Platelets and anticoagulant capacity in patients with inflammatory bowel disease. Pathophysiol Haemost Thromb 2002:32:92-6.

2 Brittenham GM, Koepke JA. Red blood cell volume distributions and the diagnosis of anemia. Help or hindrance? Arch Pathol Lab Med

1987:111:1146-8.

3 Gasche C, Scholmerich J, Brynskov J, et al. A simple classification of Crohn's disease: report of the Working Party for the World Congresses of Gastroenterology, Vienna 1998. Inflamm Bowel Dis 2000;6:8-15

4 Best WR, Becktel JM, Singleton JW, et al. Development of a Crohn's disease activity index. National Cooperative Crohn's Disease Study. Gastroenterology 1976;70:439-44.

5 Harvey RF, Bradshaw JM. A simple index of Crohn's disease activity. Lancet 1980;i:514.

6 Hanaver SB, Strömberg U. Oral pentasa in the treatment of active Crohn's disease: a meta-analysis of double-blind, placebo-controlled trials. Clin Gastroenterol Hepatol 2004;2:379-88.

7 Greenberg GR, Feagan BG, Martin F, et al. Oral budesonide for active Crohn's disease. Canadian Inflammatory Bowel Disease Study Group. N Engl J Med 1994;331:836-41.

8 Thomsen OO, Cortot A, Jewell DP, et al. A comparison of budesonide and mesalamine for active Crohn's disease. International BudesonideMesalamine Study Group. N Engl J Med 1998:339:370-4.

9 Rutgeerts $\mathbf{P}$, Lofberg $\mathrm{R}$, Malchow $\mathrm{H}$, et al. $\mathrm{A}$ comparison of budesonide with prednisolone for active Crohn's disease. N Engl J Med 1994;331:842-5.

10 Gross V, Andus T, Caesar I, et al. Oral pH-modified release budesonide versus 6-methylprednisolone in active Crohn's disease. German/Austrian Budesonide Study Group. Eur J Gastroenterol Hepatol 1996;8:905-9.

11 Campieri M, Ferguson A, Doe W, et al. Ora budesonide is as effective as oral prednisolone in active Crohn's disease. The Global Budesonide Study Group. Gut 1997;41:209-14.

12 Bar-Meir S, Chowers Y, Lavy A, et al. Budesonide versus prednisone in the treatment of active Crohn's disease. The Israeli Budesonide Study Group. Gastroenterology 1998;115:835-40.

13 Papi C, Luchetti R, Montanti S, et al. Budesonide in the treatment of Crohn's disease: a meta-analysis. Aliment Pharmacol Ther 2000;14:1419-28.

14 Kane SV, Schoenfeld P, Sandborn W, et al. Systematic review: the effectiveness of budesonide for Crohn's disease. Aliment Pharmacol Ther 2002;16:1509-17.

15 Carter GT, Ugalde V. Medical marijuana: emerging applications for the management of neurologic disorders. Phys Med Rehabil Clin N Am 2004;15:943-54.
16 Camma C, Giunta M, Rosselli M, et al. Mesalamine in the maintenance treatment of Crohn's disease: a meta-analysis adjusted for confounding variables. Gastroenterology 1997; 113:1465-73.

17 Michelassi F, Balestracci T, Chappell R, et al. Primary and recurrent Crohn's disease. Experience with 1379 patients. Ann Surg 1991;214:230-8.

18 Rutgeerts P, Geboes K, Vantrappen G, et al. Predictability of the postoperative course of Crohn's disease. Gastroenterology 1990;99:956-63.

19 Ardizzone S, Maconi G, Sampietro GM, et al. Azathioprine and mesalamine for prevention of relapse after conservative surgery for Crohn's disease. Gastroenterology 2004;127:730-40.

20 Hanauer SB, Korelitz BI, Rutgeerts P, et al. Postoperative maintenance of Crohn's disease remission with 6-mercaptopurine, mesalamine or placebo: a 2 year trial. Gastroenterology 2004; 127:723-9.

21 Cosnes J, Beaugerie L, Carbonnel F, et al. Smoking cessation and the course of Crohn's disease: an intervention study. Gastroenterology 2001;120:1093-9.

22 McGovern DPB, Travis SPL. Thiopurine therapy: when to start and when to stop. Eur J Gastroentero Hepatol 2003;15:219-24.

23 Lémann $M$, Bouhnik $Y$, Colombel J-F, et al. Randomized, double-blind, placebo-controlled, multicenter azathioprine withdrawal trial in Crohn's disease. Gastroenterology, 2002;122(suppl 4), P15.

24 Sandborn WJ. Rational dosing of azathioprine and 6-mercaptopurine. Gut 2001;48:591-2.

25 Colombel JF, Ferrari N, Debuysere H, et al. Genotypic analysis of thiopurine Smethyltransferase in patients with Crohn's disease and severe myelosuppression during azathioprine therapy. Gastroenterology 2000;1 18:1025-30.

26 Fraser AG, Orchard TR, Jewell DP. The efficacy of azathioprine for the treatment of inflammatory bowel disease: a 30 year review. Gut 2002;50:485-9.

27 Herrlinger KR, Fellermann K, Fischer C, et al. Thioguanine-nucleotides do not predict efficacy of thioguanine in Crohn's disease. Aliment Pharmaco Ther 2004; 19:1269-76

28 Wusk B, Kullak-Ublick GA, Rammert C, et al. Therapeutic drug monitoring of thiopurine drugs in patients with inflammatory bowel disease or autoimmune hepatitis. Eur J Gastroenterol Hepatol 2004; 16: 1407-13.

29 Geller SA, Dubinsky MC, Vasiliauskas EA. Early hepatic nodular hyperplasia and submicroscopic fibrosis associated with 6-thioguanine therapy in inflammatory bowel disease. Am J Surg Pathol 2004;28:1204-1 1

30 Arora S, Katkov W, Cooley J, et al. Methotrexate in Crohn's disease: results of a randomized, doubleblind, placebo-controlled trial. Hepatogastroenterology 1999;46:1724-9.

31 Feagan BG, Fedorak RN, Irvine EJ, et al. A comparison of methotrexate with placebo for the maintenance of remission in Crohn's disease. North American Crohn's Study Group Investigators. N Engl J Med 2000;342:1627-32.

32 Wenzl HH, Hinterleitner TA, Aichbichler BW, et al Mycophenolate mofetil for Crohn's disease: shortterm efficacy and long-term outcome. Aliment Pharmacol Ther 2004; 19:427-34.

33 Sheridan MB, Nicholson DA, Martin DF. Transabdominal ultrasonography as the primary investigation in patients with suspected Crohn's disease or recurrence: a prospective study. Clin Radiol 1993:48:402-4

34 Castiglione F, de Sio I, Cozzolino A, et al. Bowel wall thickness at abdominal ultrasound and the oneyear-risk of surgery in patients with Crohn's disease. Am J Gastroenterol 2004;99:1977-83.

35 Rayner CK, Hart AL, Hayward CM, et al. Azathioprine dose escalation in inflammatory bowel disease. Aliment Pharmacol Ther 2004;20:65-71.

36 Feagan BG, Rochon J, Fedorak RN, et al. Methotrexate in the treatment of Crohn's disease. N Engl J Med 1995;332:292-7.

37 Alfadhli AA, McDonald JW, Feagan BG. Methotrexate for induction of remission in refractory Crohn's disease (Cochrane Review). Cochrane Database Syst Rev, 2003;(1) CD003459.

38 Targan SR, Hanauer SB, van Deventer SJ, et al. A short-term study of chimeric monoclonal antibody cA2 to tumor necrosis factor alpha for Crohn's disease. Crohn's Disease cA2 Study Group. N Engl J Med 1997;337:1029-35.

39 Hanauer SB, Feagan BG, Lichtenstein GR, et al. Maintenance infliximab for Crohn's disease: the ACCENT I randomised trial. Lancet 2002;359:1541-9.

40 Colombel JF, Loftus EV Jr, Tremaine WJ, et al. The safety profile of infliximab in patients with Crohn's disease: the Mayo clinic experience in 500 patients Gastroenterology 2004;126:19-31.

41 Couve S, Seksik P, Elefant E, et al. Maladies inflammatoires chroniques de l'intestin et procréation. Gastroenterol Clin Biol 2003;27:618-26.

42 Korelitz BI. Inflammatory bowel disease and pregnancy. In pregnancy and gastro-intestinal disorders. Gastroenterol Clin North Am 1998;27:213-24.

43 Couckuyt H, Gevers AM, Coremans G, et al. Efficacy and safety of hydrostatic balloon dilatation of ileocolonic Crohn's strictures: a prospective longterm analysis. Gut 1995;36:577-80.

44 Thomas-Gibson S, Brooker JC, Hayward CM et al. Colonoscopic balloon dilation of Crohn's strictures: a review of long-term outcomes. Eur J Gastroenterol Hepatol 2003;15:485-8.

45 Broering DC, Eisenberger CF, Koch A, et al Strictureplasty for large bowel stenosis in Crohn's disease: quality of life after surgical therapy. Int J Colorectal Dis 2001;16:81-7. 